\title{
O znaczeniu fundamentalnych zasad karania w polityce karnej — uwagi na tle przyczyn i skutków „masowego uwięzienia” w Stanach Zjednoczonych
}

\author{
Barbara Stańdo-Kawecka \\ Zakład Prawa Karnego Wykonawczego \\ Uniwersytet Jagielloński
}

Lektura prac Profesora Tomasza Kaczmarka nie pozostawia wątpliwości co do tego, że karę kryminalną uważa on za jeden z najbardziej intrygujących poznawczo obszarów dociekań naukowych o charakterze interdyscyplinarnym. W swoich publikacjach poświęconych karze Tomasz Kaczmarek z właściwą sobie erudycją łączy perspektywę prawnokarną z podejściem filozoficznym, kryminologicznym, socjologicznym i psychologicznym. Ogromny dorobek Profesora w dziedzinie nauki o karze onieśmiela i sprawia, że podejmowanie problemów związanych z pytaniami o fundamentalne zasady karania wydaje się nazbyt odważne, lecz z drugiej strony - inspiruje do poszukiwań i refleksji nad zmianą dominujących nurtów w myśleniu o karze i karaniu.

Ubiegły wiek przyniósł z sobą istotne zmiany paradygmatów karania. Najbardziej radykalny i czasami zaskakujący charakter miały one w Stanach Zjednoczonych, co nie oznacza, że pozostawały zupełnie bez wpływu na teorię i praktykę karania w innych krajach, w tym także europejskich. Jak słusznie zauważył Andrzej Marek, kiedy pisał o upadku ideologii resocjalizacji w Stanach Zjednoczonych, radykalizm zmian ówczesnej amerykańskiej polityki karnej w Europie przyjęty został z dystansem i sceptycyzmem, lecz bez wątpienia „nowe koncepcje amerykańskie wpływały i wpływają na politykę karną w innych krajach, przyczyniając się generalnie do jej zaostrzenia"1. Wydaje się, że w ostatnich dekadach dyfuzja

1 A. Marek, Funkcje kary pozbawienia wolności na tle zmian polityki karnej, [w:] Xlat obowiązywania Kodeksu karnego wykonawczego, red. S. Lelental, G.B. Szczygieł, Białystok 2009, s. 61. 
idei w polityce karnej przybrała na sile, choć ze względu na wielość i różnorodność czynników o charakterze globalnym i lokalnym, które wpływają na kształt tej polityki w poszczególnych krajach, jest to dość trudne do oceny.

Z perspektywy amerykańskiej pierwsza radykalna zmiana paradygmatu karania nastąpiła tam w latach 70 . ubiegłego stulecia. Od końca XIX wieku aż do tego okresu teorie kary oraz polityka i praktyka karania opierały się w Stanach Zjednoczonych na ideach konsekwencjalizmu². Jest to nurt obejmujący teorie karania, które upatrują jego uzasadnienia w przyszłych skutkach (konsekwencjach) i na ogół odwołują się do filozofii utylitaryzmu. Z tego powodu główne teorie karania mieszczące się w obrębie tego nurtu określane są jako teorie utylitarne. Karanie sprawców przestępstw w świetle tych teorii jest moralnie uzasadnione, ponieważ wymierzane kary pozwalają na zmniejszenie rozmiarów przestępczości w przyszłości, pomagając tym samym w kontroli przestępczości. Zwolennicy konsekwencjalizmu wśród mechanizmów pozwalających na zmniejszenie przyszłej przestępczości zwykle wymieniają odstraszanie sprawców od popełnienia kolejnych przestępstw i odstraszanie potencjalnych sprawców (deterrence), uniemożliwianie popełnienia kolejnych przestępstw tym, którzy już wcześniej ich dokonali (incapacitation), oraz reformowanie charakteru i zachowania sprawcy, by przywrócić go społeczeństwu jako osobę przestrzegającą prawa (reform or rehabilitation $)^{3}$.

Szczytowym osiągnięciem konsekwencjalizmu w Stanach Zjednoczonych było przyjęcie w 1962 r. Wzorcowego kodeksu karnego (Model Penal Code), zawierającego podstawowe zasady karania, które powinny być uwzględniane przez ustawodawcę federalnego i ustawodawców stanowych ${ }^{4}$. Wzorcowy kodeks karny został opracowany przez prestiżowy Amerykański Instytut Prawa (American Law Institute). W pracy nad tym dokumentem, trwającej 13 lat, uczestniczyli wybitni amerykańscy naukowcy i przedstawiciele praktyki. Sam Wzorcowy kodeks karny nie był ustawą, lecz miał duży wpływ na reformy wymiaru sprawiedliwości nie tylko w Stanach Zjednoczonych, lecz także w innych krajach, w tym głównie anglojęzycznych. Zawarte w nim zalecenia ogólnie proponowały taką politykę karania, która akcentuje możliwość reformowania (poprawy) przestępców oraz długotrwałej izolacji tych, którzy zostali uznani za sprawców niepoprawnych i niebezpiecznych dla społeczeństwa. Wprowadzał on kary pozbawienia wolności - nieoznaczone i względnie oznaczone (indefinite or indeterminate sentences) — oraz przyznawał sędziom szeroką dyskrecjonalną władzę w zakresie wy-

2 M. Tonry, Can Twenty-first Century Punishment Policies Be Justified in Principle?, [w:] Retributivism Has a Past. Has It a Future?, red. M. Tonry, Oxford-New York 2011, s. 6.

3 Więcej na temat konsekwencjalizmu piszą M. Cavadino, J. Dignan, The Penal System. An Introduction, Los Angeles 2007, s. 37 n.; por. także rozważania na temat utylitarnej teorii kary W. Sadurski, Teoria sprawiedliwości. Podstawowe zagadnienia, Warszawa 1988, s. 258 n.

4 M. Tonry, op. cit., s. 7. 
boru rodzaju i wymiaru kary ${ }^{5}$. Sankcja polegająca na pozostawieniu sprawcy na wolności pod dozorem kuratora (probacja) była możliwa do zastosowania niemal w przypadku każdego przestępstwa, włącznie z zabójstwem; wyjątek stanowiły przestępstwa, za które przewidziana była obligatoryjna kara dożywotniego pozbawienia wolności albo kara śmierci ${ }^{6}$. W razie skazania sprawcy na karę pozbawienia wolności decyzję o tym, kiedy ma on opuścić więzienie, podejmowała rada ds. warunkowych zwolnień ( parole board).

Wybitni naukowcy i przedstawiciele wymiaru sprawiedliwości uczestniczący w pracach nad Wzorcowym kodeksem karnym nie traktowali proporcjonalności wymierzanej kary do ciężaru popełnionego czynu jako najważniejszego elementu systemu karania. Do idei odpłaty i proporcjonalności karania odwoływali się w nielicznych wypadkach: kiedy wskazywali, że jednym z celów tego wzorcowego kodeksu było zapewnienie, aby orzekane kary nie były nieproporcjonalnie surowe, a ponadto w tych zaleceniach, w myśl których kary nieizolacyjne i warunkowe zwolnienie nie powinny być stosowane, jeżeli mogłoby to zdeprecjonować ciężar popełnionego przestępstwa. Nadmiernie surowemu karaniu w systemie przyznającym sędziom dużą władzę dyskrecjonalną miała zapobiegać utylitarna zasada powściągliwości w karaniu (principle of parsimony). Znalazła ona odzwierciedlenie w zaleceniach, które dotyczyły szerokiego stosowania warunkowego zwolnienia oraz wyboru rodzaju kary ${ }^{7}$. Te ostatnie przewidywały, że sąd nie wymierza osobie winnej popełnienia przestępstwa kary pozbawienia wolności, z wyjątkiem tych wypadków, kiedy, w jego opinii, z uwagi na rodzaj i okoliczności przestępstwa oraz dotychczasowe życie, charakter i warunki sprawcy jest to konieczne do ochrony społeczeństwa. Wśród przesłanek wskazujących na konieczność wymierzenia kary pozbawienia wolności Wzorcowy kodeks karny wymieniał nadmierne ryzyko, że w czasie zawieszenia wykonania kary lub probacji sprawca popełni ponowne przestępstwo, potrzebę prowadzenia wobec niego oddziaływania korekcyjnego, które najskuteczniej mogło być zapewnione w zakładzie karnym, oraz opinię sądu, że łagodniejsza kara zdeprecjonowałaby ciężar popełnionego przestępstwa ${ }^{8}$.

Powszechne poparcie, jakim cieszył się Wzorcowy kodeks karny wśród teoretyków karania i praktyków wymiaru sprawiedliwości w czasie jego uchwalenia przez Amerykański Instytut Prawa, mogło sugerować, że następne dekady upłyną w Stanach Zjednoczonych pod znakiem stabilnej polityki karnej, realizowanej zgodnie ze sformułowanymi w nim zaleceniami. W rzeczywistości stało się

5 Więcej na temat Wzorcowego kodeksu karnego z 1962 r. por. Model Penal Code, [w:] Sentencing, red. H. Gross, A. von Hirsch, New York-Oxford 1981, s. 57 n.; A. Marek, op. cit., s. 62 n.; B. Stańdo-Kawecka, Prawo karne nieletnich. Od opieki do odpowiedzialności, Warszawa 2007, s. $71 \mathrm{n}$.

${ }^{6}$ Komentarz do art. 7.01 Wzorcowego kodeksu karnego zob. Model Penal Code, s. 61.

7 M. Tonry, op. cit., s. 7.

8 Art. 7.01. Wzorcowego kodeksu karnego, Model Penal Code, s. 61. 
jednak inaczej. Wkrótce po jego uchwaleniu zaczęła narastać krytyka idei, na których był on oparty, a w kilkanaście lat później nastąpiło radykalne odrzucenie proponowanego w nim resocjalizacyjnego modelu karania. Silna krytyka ideologii resocjalizacji pojawiła się w Stanach Zjednoczonych w okresie, kiedy wzrastały rozmiary przestępczości ujawnionej i poczucie zagrożenia przestępczością. Do jej upadku przyczyniło się wiele różnych czynników o charakterze politycznym, społecznym i gospodarczym, w tym zmiany na rynku pracy, wzrost napięć na tle rasowym oraz spadek zaufania do państwa. Wśród argumentów przemawiających za odrzuceniem tej ideologii nie bez znaczenia były także te, które wskazywały na rozbieżność teorii i praktycznych skutków jej implementacji. W praktyce, jak wskazywali amerykańscy kryminolodzy, idea resocjalizacji często prowadziła do nierówności i wzrostu represyjności karania, ponieważ kary orzekane na czas z góry nieoznaczony powodowały wydłużenie okresu izolacji, które w największym stopniu dotykało grupy społecznie nieuprzy wilejowane. Ponadto indywidualnoprewencyjne skutki programów resocjalizacyjnych realizowanych w obszarze probacji i więziennictwa okazały się dalekie od oczekiwanych ${ }^{9}$. Dominacja ideologii resocjalizacji z charakterystyczną dla niej koncentracją na osobie sprawcy i jego potrzebach spowodowała także, jak podnoszono w literaturze naukowej, ignorowanie wielu innych istotnych kwestii dotyczących karania, takich jak relacje pomiędzy obywatelem i państwem, legitymacja państwa do stosowania środków przymusu czy mechanizmy ogólnoprewencyjnego oddziaływania prawa karnego. Zarzuty te syntetycznie ujął Francis Allen w eseju Legal Values and the Rehabilitative Ideal, pisząc, że dominacja ideału resocjalizacji nie tylko odwracała uwagę od wielu poważnych kwestii, lecz także prowadziła do zaprzeczania, że one w ogóle istnieją ${ }^{10}$.

Norweski kryminolog Nils Christie napisał w latach 80. ubiegłego stulecia, że „światem rządzą dychotomie"l1. Załamanie się jednej ideologii karania powoduje, że „na jej grobie” pojawiają się lub odradzają inne, często przeciwstawne, koncepcje i teorie. Używając jego terminologii, można powiedzieć, że „na grobie” ideologii resocjalizacji w latach 70. XX wieku wyrosła w Stanach Zjednoczonych nowa teoria karania, a mianowicie teoria kary zasłużonej (just deserts theo$r y$ ), przedstawiona przez Andrew von Hirscha w raporcie przygotowanym przez dziewiętnastoosobową komisję pt. Doing justice: The choice of punishments ${ }^{12}$.

9 Więcej por. A. Marek, op. cit., s. 63 n.; B. Stańdo-Kawecka, op. cit., s. 73 n.

10 Por. „We are thus confronted by a situation in which the dominance of the rehabilitative ideal not only diverts attention from many serious issues but leads to a denial that these issues even exist”, F.A. Allen, Legal Values and the Rehabilitative Ideal, [w:] Sentencing, s. 113.

11 N. Christie, Granice cierpienia, przeł. L. Falandysz, Warszawa 1991, s. 32; pierwsze wydanie tej książki ukazało się w języku angielskim (Limits to pain) w $1982 \mathrm{r}$.

12 A. von Hirsch, Doing justice: The choice of punishments. Report of the Committee for the Study of Incarceration, New York 1976. 
Teoria ta, choć nie jest wolna od pewnych elementów prewencyjnych ${ }^{13}$, zdominowana została przez retrybutywne podejście do karania, które poszukuje moralnego uzasadnienia karania w uznaniu winy przestępcy i zakłada, że kara powinna być zorientowana na przeszłość, to jest na popełniony czyn, a nie na skutki, jakie przyniesie ona w przyszłości. Uzasadnieniem karania, według teorii just deserts, jest przekonanie, że sprawca zasługuje na karę. Wymiar kary powinien być dostosowany do ciężaru popełnionego przestępstwa, który zależy od rozmiaru wyrządzonej szkody oraz stopnia zawinienia sprawcy. Podstawą sprawiedliwego karania jest przestrzeganie zasady proporcjonalności kary do ciężaru zawinionego czynu. Uwzględnianie prewencyjnych celów karania, takich jak odstraszanie, uniemożliwianie czy resocjalizacja, jest możliwe jedynie o tyle, o ile nie spowoduje naruszenia zasady proporcjonalności. Ta zaś wymaga, by sprawcy skazani za podobne przestępstwa otrzymali podobnie dolegliwe kary, a skazani za przestępstwa o różnym ciężarze — kary o zróżnicowanej dolegliwości.

Teoria „kary zasłużonej” spotkała się w Stanach Zjednoczonych z aprobatą nie mniejszą od tej, z jaką wcześniej traktowano resocjalizacyjny model karania. $\mathrm{Z}$ dużym zainteresowaniem przyjęto ją także w Europie ${ }^{14}$, choć poparcie dla resocjalizacji jako zasady karania było tu ograniczone i nigdy nie nastąpiło oderwanie wymiaru kary od ciężaru zawinionego czynu tak dalece, jak miało to miejsce w Stanach Zjednoczonych. Pojawienie się tej teorii ogólnie spowodowało ożywienie dyskusji na temat filozofii karania, a w szczególności na temat retrybutywizmu i jego odmian w literaturze anglosaskiej ${ }^{15}$. W krótkim czasie w naukowych i publicznych debatach na temat karania akcent przesunął się z resocjalizacji sprawców jako dominującego celu karania w kierunku odpłaty i just deserts. Konsekwencjalizm ustąpił zatem miejsca retrybutywizmowi ${ }^{16}$, a co za tym idzie — koncepcja kary wymierzanej według właściwości i potrzeb sprawcy została zastąpiona koncepcją kary proporcjonalnej do ciężaru zawinionego czynu. W połowie lat 70. ubiegłego wieku dyskusje kryminalnopolityczne w Stanach Zjednoczonych koncentrowały się wokół stwierdzenia nothing works („nic nie działa"), które odzwierciedlało przekonanie, że programy resocjalizacyjne realizowane $\mathrm{w}$ więziennictwie i probacji nie mają wpływu na poziom powrotności

13 M. Tonry zalicza teorię just deserts do teorii mieszanych, łączących elementy retrybutywizmu i utylitaryzmu, znajdujących się w różnych punktach kontinuum pomiędzy czystą teorią retrybutywną (Kanta) i czystą teorią utylitarną (Benthama). Więcej por. M. Tonry, Purposes and Functions of Sentencing, „Crime and Justice” 34, 2006, nr 1, s. $20 \mathrm{n}$.

14 O reformach prawa karnego zmierzających do zagwarantowania proporcjonalności między przestępstwem i karą oraz przejrzystości i określoności prawa w krajach skandynawskich pisze między innymi N. Christie, op. cit., s. $48 \mathrm{n}$.

15 W. Sadurski, op. cit., s. 251.

16 Więcej na temat retrybutywnej teorii kary i różnych wersji retrybutywizmu por. ibidem, s. $241 \mathrm{n}$. 
uczestniczących w nich skazanych do przestępstwa ${ }^{17}$. Na przełomie lat 70. i 80 . najbardziej wpływowym stwierdzeniem w takich dyskusjach było już nie nothing works, leczjust deserts, ponieważ ich kluczowym punktem stała się problematyka kary zasłużonej. Po upadku ideologii resocjalizacji w centrum zainteresowania teoretyków prawa i praktyków wymiaru sprawiedliwości znalazło się karanie traktowane jako wyraz moralnej odpowiedzialności sprawcy i publicznego potępienia go za przestępcze zachowanie ${ }^{18}$.

Ruch reformowania amerykańskiego systemu karania, zapoczątkowany w latach 70. ubiegłego stulecia przez raport przygotowany pod przewodnictwem Andrew von Hirscha i jego teorię kary zasłużonej, w założeniu miał prowadzić do liberalizacji polityki karnej i ograniczenia rozmiarów populacji więziennej. W świetle tego raportu powrót do retrybutywnej teorii karania miał przywrócić sprawiedliwość karania i zmniejszyć represyjność wcześniejszego systemu, który umożliwiał nadużywanie długoterminowych kar pozbawienia wolności w imię resocjalizacji skazanych. W praktyce założenia te były realizowane w latach 70. i 80 . ubiegłego wieku przez wprowadzanie na poziomie federalnym i stanowym reform, które ograniczały dyskrecjonalną władzę sędziów i przewidywały kary proporcjonalne do ciężaru popełnionego przestępstwa. W wielu stanach uchwalano ustawy, które wprowadzały kary pozbawienia wolności o oznaczonej długości, wydawano dyrektywy karania (sentencing guidelines) mające na celu ujednolicenie wymiaru kary za poszczególne przestępstwa oraz rezygnowano $\mathrm{z}$ dyskrecjonalnego warunkowego zwolnienia skazanych z zakładów karnych ${ }^{19}$. Retoryka „zasłużonego karania" (deserved punishment), jak zauważył Michael Tonry, była powszechna nie tylko w dyskursie naukowym, lecz także wśród polityków. W rezultacie w tym okresie wydawało się, że przynajmniej w Stanach Zjednoczonych retrybutywizm na długo zastąpi konsekwencjalizm i zapewni stabilną politykę karną ${ }^{20}$. Jednak, podobnie jak w przypadku ideologii resocjalizacji, i tym razem zmiany przyszły szybko i miały dość gwałtowny charakter.

Federalne i stanowe ustawy uchwalane w Stanach Zjednoczonych w drugiej połowie lat 80 . i w latach 90 . XX wieku, które wprowadzały zmiany systemu karania, nie miały już wiele wspólnego z ideą kary zasłużonej, proporcjonalnej do ciężaru zawinionego czynu, zgodnie z którą sprawiedliwa reakcja na przestępstwo musi uwzględniać równość horyzontalną (,traktuj podobne sprawy podob-

17 Sformułowanie nothing works było uproszczonym i metodologicznie nieuzasadnionym podsumowaniem wyników badań przeprowadzonych przez D. Liptona, R. Martinsona i J. Wilks nad skutecznością programów resocjalizacyjnych realizowanych głównie w amerykańskich więzieniach w latach 1945-1967. Więcej por. A. Marek, op. cit., s. 63; B. Stańdo-Kawecka, op. cit., s. 74 n.

18 The Growth of Incarceration in the United States: Exploring Causes and Consequences, red. J. Travis, B. Western, 2014, s. 321 n., https://www.nap.edu/login.php?record id=18613\&page=https\%3A\%2F\%2Fwww.nap.edu\%2Fdownload\%2F18613 (dostęp: 30.09.2016).

19 M. Tonry, Purposes..., s. 18.

20 M. Tonry, Can Twenty-first..., s. 3. 
nie”) i wertykalną (,traktuj różne sprawy różnie”) ${ }^{21}$. Zmierzały one do zaostrzania kar wymierzanych za pewne przestępstwa lub pewnym kategoriom sprawców na podstawie teorii odstraszania (deterrence) i uniemożliwiania (incapacitation). W nurcie polityki karnej opartej na odstraszaniu mieściły się ustawy wprowadzające karę dożywotniego pozbawienia wolności bez możliwości warunkowego zwolnienia oraz obligatoryjne kary minimalne za pewne przestępstwa, głównie za przestępstwa narkotykowe i popełnione $\mathrm{z}$ użyciem broni. Ustawy regulujące wymiar kary za przestępstwa narkotykowe ${ }^{22}$ często przewidywały dla ulicznych dilerów obligatoryjne minimalne kary pozbawienia wolności, surowsze od tych orzekanych wobec sprawców poważnych przestępstw, takich jak napaść, rozbój, gwałt, a nawet wobec sprawców niektórych zabójstw ${ }^{23}$. Z kolei do koncepcji uniemożliwiania czy też selektywnego uniemożliwiania (selective incapacitation) odwoływały się ustawy typu „three strikes and you are out”, które wprowadzały obligatoryjne długoterminowe kary pozbawienia wolności w razie skazania sprawcy za trzecie z kolei przestępstwo ${ }^{24}$. Tego typu ustawy były nie do pogodzenia z zasadą proporcjonalności kary do ciężaru zawinionego czynu i w praktyce nierzadko uruchamiały procesy „obchodzenia prawa” przez prokuratorów i sędziów, którzy uznawali przewidziane w nich kary obligatoryjne za niesprawiedliwie surowe i sprzeczne z powszechnymi odczuciami na temat relatywnego ciężaru różnych przestępstw ${ }^{25}$. Ustawy odwołujące się do koncepcji odstraszania i uniemożliwiania nie tylko pozostawały w sprzeczności z zasadą proporcjonalności, lecz także naruszały zasadę powściągliwości w karaniu, w myśl której wymierzane kary nie powinny być surowsze niż jest to konieczne dla osiągnięcia zakładanego celu ${ }^{26}$.

Ruch zmierzający do reformowania amerykańskiej polityki karnej przez przywrócenie sprawiedliwości karania, jaki rozwinął się po upadku ideologii re-

21 Ibidem.

22 Przykładem takiej ustawy może być ustawa federalna z 1986 r. (Anti-Drug Abuse Act), która wprowadziła surowe obligatoryjne minimalne kary pozbawienia wolności dla sprawców skazanych za posiadanie niewielkiej ilości kokainy typu crack; w przypadku sprawcy skazanego za posiadanie 5 g kokainy typu crack obligatoryjna kara minimalna wynosiła 5 lat pozbawienia wolności, a w razie skazania za posiadanie $50 \mathrm{~g}$ takiej kokainy - 10 lat pozbawienia wolności.

23 M. Tonry, Can Twenty-first..., s. 9.

${ }^{24}$ Ustawy typu ,three strikes and you are out” uchwalane w poszczególnych stanach różniły się od siebie. Przykładem szczególnie restrykcyjnej ustawy tego typu była ta przyjęta w Kalifornii, zgodnie z którą sprawcy jakiegokolwiek przestępstwa, który uprzednio był dwukrotnie skazany za wymienione enumeratywnie przestępstwa, sąd obligatoryjnie wymierzał karę od 25 lat do dożywotniego pozbawienia wolności. Więcej por. B. Stańdo-Kawecka, op. cit., s. 84 n. W polskiej literaturze kryminologicznej aprobująco o ustawie kalifornijskiej wypowiadał się J. Czabański, pisząc, że okazała się ona kontrowersyjnym, ale skutecznym narzędziem powstrzymania przestępczości (J. Czabański, Kalifornijskie prawo three strikes and you're out: próba oceny, cz. II, „Palestra” 2006, nr 9-10, s. 237).

25 M. Tonry, Purposes..., s. 25 n.

26 The Growth of Incarceration..., s. 322. 
socjalizacji, szybko przerodził się zatem w ruch zorientowany na zaostrzanie kar w imię odstraszania oraz długoterminowego izolowania sprawców uznanych za groźnych dla społeczeństwa. Po kilku dekadach (lata 1920-1970) stabilnej i relatywnie niskiej populacji więziennej wraz z odrzuceniem resocjalizacyjnego modelu karania w Stanach Zjednoczonych rozpoczął się trwający ok. 40 lat wzrost liczby uwięzionych. Tempo tego wzrostu było zjawiskiem bezprecedensowym w historii tego kraju, a jego skala była nieporównywalna z tym, co działo się w polityce karnej innych krajów zachodnich, które pod koniec XX w. także doświadczyły „punitywnego zwrotu” w polityce karnej. W latach 1973-2009 populacja osób pozbawionych wolności w więzieniach stanowych i federalnych zwiększyła się z ok. 200 tys. do ponad 1,5 $\mathrm{mln}^{27}$. Przy uwzględnieniu ponad 750 tys. osób pozbawionych wolności w aresztach lokalnych populacja osób uwięzionych w 2009 r. osiągnęła poziom 2,3 mln (wykres 1). O ile w roku 1972 współczynnik uwięzionych w aresztach lokalnych oraz więzieniach stanowych i federalnych wynosił 161 osób na 100 tys. mieszkańców, to w ciągu następnych 40 lat wzrósł ponad czterokrotnie i w roku 2012 wynosił $707^{28}$. Po roku 1989, w którym liczba uwięzionych przekroczyła $1 \mathrm{mln}$, w ciągu kilkunastu następnych lat uległa ona zwiększeniu o kolejny milion - w roku 2002 przekroczyła już $2 \mathrm{mln}$. W ostatnich latach (od roku 2009) wzrost liczby osób pozbawionych wolności się zatrzymał, a nawet odnotowano jej niewielki spadek. Jak wskazuje wykres 1 - spadek rozpoczął się wcześniej i jest bardziej widoczny w aresztach lokalnych i więzieniach stanowych niż w więzieniach federalnych; w tych ostatnich spadek liczby uwięzionych wystąpił dopiero w 2013 r. Nieznaczne zmniejszenie się populacji osób pozbawionych wolności w ostatnich latach nie zmienia faktu, że współczynnik uwięzionych w Stanach Zjednoczonych nadal jest 5 do 10 razy wyższy niż w krajach Europy Zachodniej.

Przyczyny obserwowanego w ostatnich dekadach zjawiska ,masowego uwięzienia" oraz jego skutki dla więźniów, ich rodzin, społeczności, z których się wywodzą, i całego społeczeństwa były przedmiotem licznych badań naukowych. Obszerne prace w tym zakresie przeprowadziła między innymi specjalna komisja (Committee on Causes and Consequences of High Rates of Incarceration) złożona z przedstawicieli różnych dziedzin nauki, takich jak kryminologia, socjologia, psychologia, ekonomia, medycyna, nauki polityczne, oraz praktyków wymiaru sprawiedliwości. Komisja ta została powołana przez Krajową Radę ds. Badań (National Research Council) działającą w obrębie Krajowej Akademii Nauk ( $N a-$ tional Academy of Sciences), która jest stowarzyszeniem skupiającym wybitnych naukowców i ma status ciała doradczego dla rządu federalnego ${ }^{29}$. Zadaniem ko-

27 Ibidem, s. 2.

28 Ibidem, s. 13.

29 Powołując komisję ad hoc ds. przyczyn i skutków wysokiego poziomu inkarceracji, Krajowa Rada ds. Badań (National Research Council) działała na zlecenie Krajowego Instytutu Spra- 
Wykres 1. Liczba osób pozbawionych wolności w aresztach lokalnych oraz więzieniach stanowych i federalnych w latach 1980-2014

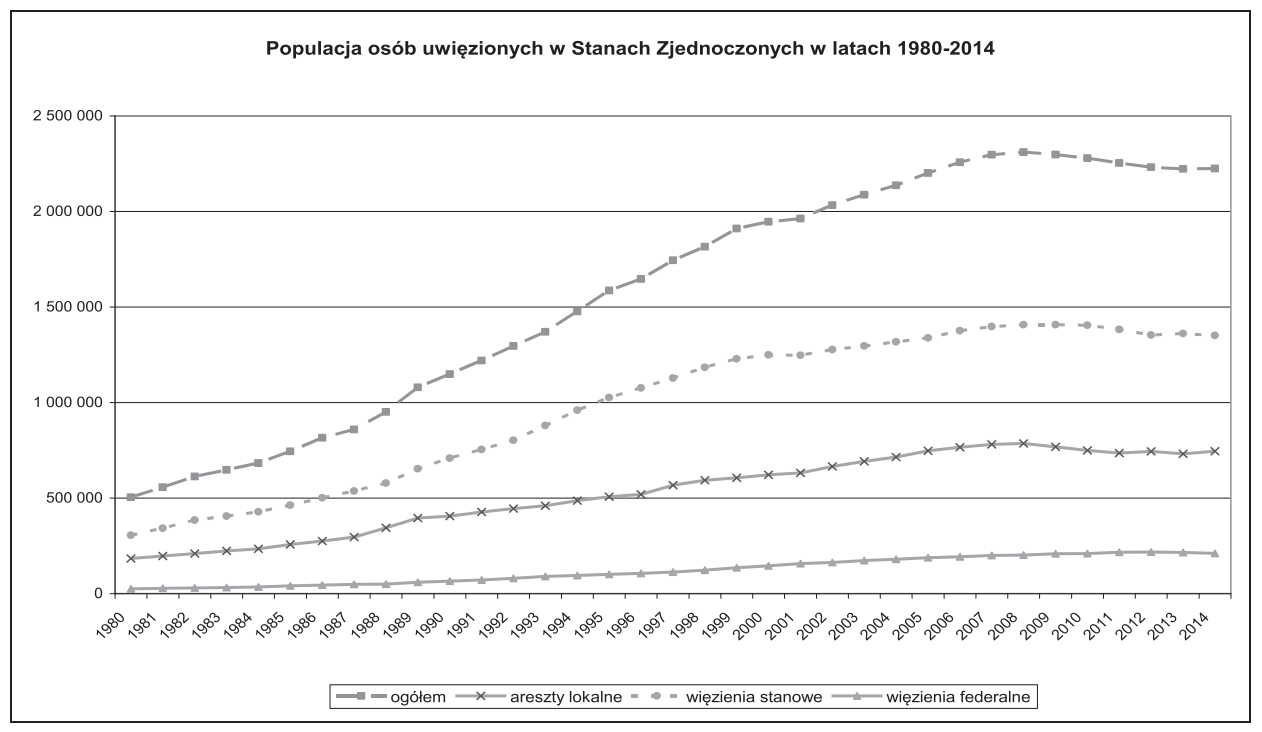

Źródło: Bureau of Justice Statistics, Estimated number of persons supervised by U.S. adult correctional systems, by correctional status, 1980-2014, http://www.bjs.gov/index.cfm?ty=kfdetail\&iid=487 (dostęp: 30.09.2016).

misji był przegląd i podsumowanie badań dotyczących przyczyn i skutków wysokiego poziomu populacji więziennej w Stanach Zjednoczonych, a swój raport przedstawiła ona w 2014 r., po dwóch latach pracy ${ }^{30}$.

Wyniki pracy specjalnej komisji oraz inne analizy kryminologiczne i socjologiczne $^{31}$ wskazują na to, że polityka „masowego uwięzienia” w Stanach Zjednoczonych uwarunkowana była wieloma czynnikami, które w poszczególnych stanach zaznaczyły się z różną siłą. W świetle tych analiz amerykańska polityka karna w ostatnich kilku dekadach była fragmentaryczna, wielowymiarowa i często wzajemnie sprzeczna. O jej ostatecznym kształcie decydowała niejasna mieszanina rozwiązań długofalowych i reform o charakterze ad hoc, podejmowanych w odpowiedzi na bieżące wydarzenia ${ }^{32}$. Te ostatnie reformy często polegały na uchwalaniu ustaw proponowanych przez polityków pod wpływem nagłośnionych w mediach pojedynczych przestępstw i nierzadko towarzyszył im brak refleksji nad ich skutkami w dłuższej perspektywie. Takie reformy w wielu wypadkach miały charakwiedliwości (National Institute of Justice) w Departamencie Sprawiedliwości Stanów Zjednoczonych i fundacji MacArthurów.

30 The Growth of Incarceration...

31 Por. np. D.H. Drake, Prison expansionism, [w:] Handbook on Prisons, red. Y. Jewkes, J. Bennett, B. Crewe, Oxon-New York 2016, s. 101 n. oraz literatura tam cytowana.

32 Ibidem, s. 103. 
ter instrumentalny i były traktowane przez polityków jako narzędzie do realizacji własnych celów, które nie miały nic wspólnego z wymierzaniem sprawiedliwości ${ }^{33}$.

Z perspektywy kilku dekad społeczne i finansowe skutki zwiększania represyjności systemu karania okazały się dramatyczne. Budowa i utrzymanie więzień dla coraz większej liczby skazanych stały się poważnym obciążeniem dla budżetu federalnego i budżetów stanowych. Wysokie koszty utrzymania dużej liczby skazanych w zakładach karnych prowadziły do redukowania nakładów przeznaczonych wcześniej na opiekę zdrowotną dla więźniów, programy terapeutyczne i resocjalizacyjne realizowane w zakładach karnych i w okresie warunkowego zwolnienia oraz pomoc postpenitencjarną po zakończeniu odbywania kary. Skazani, opuszczający przeludnione zakłady karne bez przygotowania do zwolnienia i pozbawieni wsparcia po zwolnieniu, w wielu wypadkach w krótkim czasie powracali do przestępstwa. Więzienna brama stawała się dla nich „drzwiami obrotowymi”, które oddzielały więzienie od krótkich pobytów na wolności. Ujemne skutki takiej polityki karnej dotykały nie tylko samych skazanych, lecz także ich rodziny oraz społeczności, z których się wywodzili, a szczególnie obciążały społeczności złożone z osób ubogich i kolorowych (Afroamerykanów i Latynosów). Wyniki licznych badań naukowych nie dostarczyły zaś dowodów na to, by szybki i kosztowny wzrost liczby uwięzionych powodował znaczącą redukcję przestępczości ${ }^{34}$.

W czasach, kiedy ujemne skutki represyjnej polityki karnej stały się dość oczywiste nawet dla wcześniejszych zwolenników zaostrzania kar, w Stanach Zjednoczonych ponownie toczą się dyskusje podobne do tych z lat 70. ubiegłego wieku. Tak jak wtedy, również i teraz dotyczą one przywrócenia racjonalności, sprawiedliwości i skuteczności karania. W literaturze naukowej poświęconej tym zagadnieniom podkreśla się, że budowanie racjonalnych, sprawiedliwych i skutecznych systemów karania nie jest możliwe bez zrozumienia, dlaczego wymierza się kary i co w ten sposób można osiągnąc ${ }^{35}$. Analizy amerykańskiej polityki karnej w ciągu ostatnich 40 lat wskazują na to, że wiele uchwalanych w tym czasie ustaw zmierzało do zaostrzenia karania bez refleksji nad adekwatnością surowych kar do ciężaru popełnionych czynów. Liczne ustawy zmierzały do kontroli przestępczości opartej na strategiach odstraszania i uniemożliwiania bez rozważenia kwestii, czy zaostrzanie kar było konieczne do osiągnięcia zakładanych celów ${ }^{36}$. W kontekście polityki karnej, w której przez kilka dekad pomijano istotne pytania o normatywne uzasadnienia karania i praktyczne długofalowe skutki wprowadzanych reform, obecnie ta problematyka nabiera szczególnego znaczenia.

Autorzy wspomnianego, obszernego raportu na temat przyczyn i skutków wysokiego poziomu populacji więziennej nie kwestionują pozytywnego charak-

${ }^{33}$ M. Tonry, Purposes..., s. 9.

34 The Growth of Incarceration..., s. 130 n.; M. Tonry, Purposes..., s. 28 n.

35 M. Tonry, Purposes..., s. 6

36 The Growth of Incarceration..., s. 322. 
teru działań podejmowanych przez organy państwa, które zmierzają do pociągania sprawców przestępstw do odpowiedzialności i do kontroli przestępczości, lecz zwracają uwagę na to, że takie działania wymagają równoważenia przez zasady normatywne ograniczające państwową władzę karania. Do normatywnych zasad karania, które ujmowane łącznie tworzą podstawy sprawiedliwego karania i zabezpieczają przed nadmiernym stosowaniem kar oraz innych środków penalnych pozbawiających wolności, zaliczają oni zasady proporcjonalności, powściągliwości w karaniu, obywatelstwa i sprawiedliwości społecznej ${ }^{37}$.

Proporcjonalność karania w ujęciu autorów raportu nie oznacza odmierzania kar ściśle według ciężaru czynu i moralnego zawinienia sprawcy, lecz pełni funkcję limitującą wymiar kary zgodnie z koncepcją ograniczającego retrybutywizmu Norvala Morrisa. Według autora tej koncepcji, przedstawionej w latach 70. ubiegłego wieku ${ }^{38}$, możliwość osiągnięcia konsensusu co do tego, jaka kara jest karą zasłużoną za konkretne przestępstwo, jest niewielka. W przypadku każdego przestępstwa można jednak osiągnąć szeroki konsensus co do tego, że pewne kary byłyby nadmiernie surowe, a inne zbyt łagodne. W tej wersji ograniczającego retrybutywizmu ciężar zawinionego czynu wyznacza górną, a w przypadku niektórych przestępstw - także dolną granicę kary. Punktem wyjścia dla sprawiedliwego karania za konkretne przestępstwo jest ten przedział kar, które nie są niezasłużone (not undeserved), to znaczy nie są nadmiernie surowe ani zbyt łagodne. W przedziale kar, które nie są niezasłużone, każda kara może być sprawiedliwa. W wolnym społeczeństwie obowiązuje Benthamowska zasada powściągliwości w karaniu, która przesądza o tym, że kara mieszcząca się w przedziale kar, które nie są niezasłużone, powinna być wymierzana w dolnych granicach tego przedziału. Wymierzenie kary powyżej dolnej granicy jest możliwe, jeżeli przemawiają za tym istotne względy prewencyjne, lecz w żadnym wypadku wymierzona kara nie może przekroczyć górnej granicy tego przedziału.

Koncepcja ograniczającego retrybutywizmu Norvala Morrisa cieszy się obecnie dużą popularnością wśród naukowców i praktyków proponujących kierunki reformowania amerykańskiej polityki karnej, ponieważ nie tylko wskazuje ona na ograniczenia państwowej władzy karania, lecz także zapewnia odpowiednie miejsce w systemie sprawiedliwego karania aktualnej wiedzy na temat ryzyka recydywy i skuteczności oddziaływań korekcyjnych. Tak długo, jak długo kara wymierzana w indywidualnym wypadku mieści się w przedziale kar, które nie są nadmiernie surowe ani zbyt łagodne, sąd przy podejmowaniu decyzji o karze może uwzględniać informacje istotne z punktu widzenia celów indywidualnoprewencyjnych, dotyczące szacowanego ryzyka powrotu sprawcy do przestępstwa, możliwości obniżenia tego ryzyka przez jego udział w odpowiednio zaprojektowanych

37 Ibidem, s. 323.

38 N. Morris, The Future of Imprisonment, Chicago 1974; idem, Punishment, Desert and Rehabilitation, [w:] Sentencing, s. 257 n. 
i realizowanych programach korekcyjnych oraz jego motywacji do uczestniczenia w takich programach. Tym samym koncepcja ograniczającego retrybutywizmu pozwala na integrowanie zasad proporcjonalności i powściągliwości w karaniu z osiągnięciami nurtu, który proponuje politykę karną opartą na wynikach badań naukowych określających warunki skutecznych interwencji korekcyjnych ${ }^{39}$. Atrakcyjność koncepcji ograniczającego retrybutywizmu dla współczesnych systemów karania wynika zatem stąd, że wydaje się ona w sposób optymalny równoważyć intuicje moralne na temat karania i wiedzę na temat praktycznych aspektów skutecznego ograniczania przestępczości ${ }^{40}$. Zapewne z tego powodu Amerykański Instytut Prawa przyjął tę koncepcję jako teoretyczną podstawę systemu karania w pracach nad aktualną wersją Wzorcowego kodeksu karnego ${ }^{41}$.

W konkluzjach raportu na temat przyczyn i skutków wysokiego poziomu populacji więziennej w Stanach Zjednoczonych jego autorzy poza zasadami proporcjonalności i powściągliwości karania sporo uwagi poświęcają także zasadom obywatelstwa i sprawiedliwości społecznej. Zasada obywatelstwa (principle of citizenship) dotyczy szczególnie przestępców pozbawionych wolności. Wymaga ona, aby pozbawienie wolności nie ograniczało drastycznie statusu jednostki jako członka społeczeństwa. Pomijając nieliczne wyjątki, skazani na karę pozbawienia wolności po odbyciu kary wracają do społeczeństwa. Poszanowanie zasady obywatelstwa oznacza, że kary pozbawienia wolności nie mogą być tak surowe i mieć tak poważnych długotrwałych ujemnych konsekwencji, które definitywnie wykluczałyby ukaraną osobę z pełnego uczestnictwa w życiu społecznym. Implementacja tej zasady wymaga od władz podjęcia pozytywnych działań mających na celu między innymi zapewnienie poszanowania godności i autonomii osób uwięzionych, zapewnienie warunków uwięzienia zwiększających szanse na pozytywną integrację społeczną po zwolnieniu, przygotowanie skazanych do zwolnienia oraz rewizję dotychczasowych ograniczeń nakładanych na byłych więźniów ${ }^{42}$. Doceniając znaczenie orzecznictwa Sądu Najwyższego USA w sprawach związanych

39 Na temat ruchu ,what works?” (,co działa?”) i założeń polityki karnej opartej na wynikach badań naukowych (evidence based criminal policy) por. między innymi: A. Barczykowska, S. Dzierzyńska-Breś, M. Muskała, Systemy oddziaływań resocjalizacyjnych Anglii i Stanów Zjednoczonych Ameryki, Poznań 2015, s. 41 n.; B. Stańdo-Kawecka, Wykonywanie kary pozbawienia wolności z perspektywy współczesnej penologii, [w:] Polski system penitencjarny. Ujęcie integralno-kulturowe, red. P. Szczepaniak, Warszawa 2013, s. 14 n.; eadem, Ruch What works $i$,nowa resocjalizacja" - nowa perspektywa w polityce karnej?, [w:] Węzłowe problemy prawa karnego, kryminologii i polityki kryminalnej. Ksiegga pamiatkowa ofiarowana Profesorowi Andrzejowi Markowi, red. V. Konarska-Wrzosek, J. Lachowski, J. Wójcikiewicz, Warszawa 2010, s. 902 n. oraz literatura tam cytowana.

40 M. Tonry, Purposes..., s. 23.

41 Por. Model Penal Code: Sentencing. Tentative Draft No. 4 (April 11, 2016), https://robinainstitute.umn.edu/publications/model-penal-code-sentencing-tentative-draft-no-4, s. 5 (dostęp: 30.09.2016).

42 The Growth of Incarceration..., s. 327 n. 
z naruszeniem ósmej poprawki do Konstytucji, która zakazuje kar okrutnych i niezwykłych, autorzy raportu zalecają tworzenie i umacnianie niezależnych organów monitorujących stan więzień na wzór Europejskiego Komitetu ds. zapobiegania torturom oraz nieludzkiemu lub poniżającemu traktowaniu albo karaniu ${ }^{43}$.

Ostatnia z normatywnych zasad karania, które w świetle tego raportu powinny łącznie stanowić podstawy systemu sprawiedliwego karania, to zasada sprawiedliwości społecznej ( principle of social justice). Wyniki badań przytoczonych w raporcie wskazują na to, że wśród skazanych za przestępstwa, a szczególnie wśród odbywających karę pozbawienia wolności, nadreprezentowane są osoby ubogie, o niskim poziomie wykształcenia i niskich kwalifikacjach zawodowych, mające problemy ze zdrowiem psychicznym, uzależnieniami i zapewnieniem sobie środków utrzymania. Autorzy raportu zwracają uwagę na problemy, z jakimi wiąże się stosowanie zasady równości wobec prawa w społeczeństwie, w którym nierówny jest dostęp do dóbr, zasobów i możliwości. Zasada sprawiedliwości społecznej jako normatywna zasada karania wymaga, by wymiar sprawiedliwości w sprawach karnych przyczyniał się do sprawiedliwości społecznej przez wspieranie uczciwej dystrybucji praw, zasobów i możliwości zamiast pogłębienia istniejących nierówności społecznych ${ }^{44}$.

Amerykańska polityka karna w ostatnich dekadach miała wiele cech specyficznych, które w ogóle nie występowały bądź nie występowały w takim nasileniu w innych rozwiniętych krajach demokratycznych. Jeśli jednak chodzi o fragmentaryczność polityki karnej, współwystępowanie wielu niejednokrotnie wzajemnie sprzecznych nurtów i brak spójnej wizji wymiaru sprawiedliwości w sprawach karnych, to nie są to bynajmniej zjawiska typowe wyłącznie dla Stanów Zjednoczonych. Coraz bardziej jaskrawe ujemne skutki polityki „masowego uwięzienia” w tym kraju wskazują na niebezpieczeństwa wynikające z lekceważenia podstawowych zasad karania, chroniących przed nadużyciami państwowej władzy karania, oraz zachęcają do poważnej dyskusji na temat integrowania teorii kary $\mathrm{z}$ wiedzą empiryczną o skutkach orzekania i wykonywania kar.

\section{The importance of the fundamental principles of punishment in criminal policy — remarks against a background of causes and results of "mass incarceration" in the United States}

\section{Summary}

In the last century, in the United States, there was a significant change in the paradigms of punishment. In the 1970s the ideology of rehabilitation collapsed and reforms, which aimed at restoring justice in punishment and reduction of the prison population, were initiated. In the

\footnotetext{
43 Ibidem, s. 351.

${ }^{44}$ Ibidem, s. $330 \mathrm{n}$.
} 
next decade, the movement aiming at liberal reforms lost the social and political support and was replaced with the repressive criminal policy. At the same time, a rapid increase in the prison population started which has been referred to in the criminological literature as the phenomenon of mass incarceration. After four decades of continuous growth in the number of persons deprived of their liberty there is no doubt that the social and financial consequences of a repressive system of punishment proved to be dramatic. For this reason, issues concerning the restoration of justice and rationality in punishment have again been discussed in the United States.

Many European countries also experienced the "punitive turn" in the criminal policy at the end of the 20th century, although its scale was incomparable with what happened in the United States. It does not mean, however, that American discussions on the philosophy of punishment and criminal policy are irrelevant for Europe. Multidimensional negative effects of the American policy of mass incarceration indicate the dangers resulting from ignoring the basic principles of punishment that protect against abuses of the state's power to punish. Additionally, they encourage a serious discussion about the integration of punishment theories with the empirical knowledge on the results of sentencing and sentence enforcement.

Keywords: consequentialism, retributivism, criminal policy, mass incarceration, principles of punishment. 